\title{
Envisioning Innovation at the Intersection of Sport and Disability: A Blueprint for American Higher Education
}

\author{
Dr. Derek Van Rheenen \\ University of California, Berkeley \\ Matt Grigorieff \\ University of California, Berkeley \\ Jessica N. Adams \\ University of California, Berkeley
}

Abstract: In January 2013, the United States Department of Education's Office of Civil Rights (OCR) issued policy guidelines to ensure that students with disabilities have equal opportunities to participate in extracurricular athletic activities in public elementary, secondary, and postsecondary schools. To date, few educational institutions, particularly within higher education, have met this national need. This paper describes a pilot course offered at a large public university on the west coast of the United States that combines learning about disability studies while participating in goalball, a sport designed for individuals with visual impairments. The implementation of this pilot program highlights the challenges and opportunities for educational institutions to offer students with disabilities, particularly students with visual impairments, equal opportunities to participate in athletics. This paper envisions innovation at

the intersection of sport and disability and offers a possible blueprint for other colleges and universities that seek to create similar extra or co-curricular opportunities in line with the OCR's policy guidelines.

Keywords: Higher Education, Goalball, Sport, Disability, Innovation, Visual Impairment

One of the most pressing civil rights issues of the twenty-first century is the continuing need to provide access and accommodation for individuals with disabilities, particularly within educational institutions. As a result of the historical exclusion of students with disabilities from extracurricular activities, such as club, intramural, interscholastic or intercollegiate athletics, there is a particular need for schools to provide access to these activities at all educational levels.

This paper provides a blueprint for the development of a course at the intersection of sport and disability studies. The course was designed to provide a co-curricular opportunity for students with visual impairments to participate in goalball, a sport developed specifically for people with visual impairments rather than an activity modified from a sport originally known and practiced by sighted participants (Chamalian, 2000). While only a few students with visual impairments 
initially enrolled in the course, the class also included sighted students, as well as community members with visual impairments who were invited to participate. The integration of these distinct groups provided an innovative model for the future of sport and disability studies within American higher education in an effort to reduce barriers to participation, promote inclusive environments through inter-group contact (Allport, 1954; Slininger, Sherrill \& Jankowski, 2000; Tripp, French, \& Sherrill, 1995), and complement the university's desire to incorporate disability studies into the general curriculum. The implementation of this pilot program at this university highlights the challenges and opportunities for educational institutions to offer students with disabilities, particularly students with visual impairments, equal opportunities to participate in athletics.

The success of the pilot program has yielded significant positive media attention. The university's public affairs office produced a video clip about the course and wrote a story for the campus website (Cockrell, 2013; Kell, 2014). Subsequent coverage has resulted in over 30 media features with the CBS National Evening news highlight becoming a top 10 news story for this larger public university (Blackstone, 2013; University of California Television, 2013). Other stories about the course were featured in the campus newspaper, the website for graduate students, and the Campus Alumni Magazine (Cerles, 2014; Ding, 2014; Mabanta, 2013; Seligman, 2014). In addition to this significant campus attention, local, national and even international print and electronic media ran stories about the goalball class at this university (Asimov, 2014; Blackstone, 2013; Melendez, 2013). The class clearly captured public and institutional interest at a given moment in time, prompting interest from other educational institutions to replicate a similar program at their respective schools. As such, this paper attempts to envision an innovative approach to offer athletic opportunities to students with physical disabilities at a large public university.

This paper initially provides a historical context of the legal mandates designed to protect the rights of students with disabilities, particularly as these laws pertain to providing athletic opportunities within educational institutions in the United States. Drawing parallels to the language and interpretation of Title IX of the Education Amendment of 1972, this paper frames the current field of sport and disability studies over 40 years since the passage of Title IX and Section 504 of the Rehabilitation Act of 1973. The final section of this paper describes a pilot course offered at this university, providing a possible blueprint for other colleges and universities who seek to create similar extra or co-curricular opportunities. The blueprint outlines the course design and learning outcomes of this co-curricular opportunity. This section also describes several logistical challenges associated with offering a goalball pilot program at the post-secondary level. The paper concludes with future directions and potential innovations at the intersection of sport and disability studies.

\section{Historical Context}

In January 2013, the United States Department of Education's Office of Civil Rights (OCR) issued policy guidelines to ensure that students with disabilities have equal opportunities to participate in extracurricular athletic activities in public elementary, secondary, and postsecondary schools. Specifically, the document entitled "Students with Disabilities in Extracurricular Activities" stipulates that educational institutions should make reasonable modifications and provide necessary accommodations to ensure that these equal opportunities are 
made available, unless the institution can demonstrate that providing such modifications and accommodations would be a fundamental alteration to its existing programs.

The OCR's guidance document focuses primarily on the elementary and secondary school context, but notes that "students with disabilities at the postsecondary level must also be provided an equal opportunity to participate in athletics, including intercollegiate, club, and intramural athletics" (p. 2). While the document does not add requirements to applicable law, the guidelines provide examples "to inform recipients how OCR evaluates whether covered entities are complying with their legal obligations" (p. 2). The document concludes: "Individuals who believe they have been subjected to discrimination may file a complaint with OCR or in court" (p. 12).

The U.S. Department of Education's 2013 guidelines did not create new legal requirements. The document simply provided a clarification of existing laws, prompted by a United States Government Accountability Office (GAO) report, which found that students with disabilities participated in athletics at consistently lower rates than students without disabilities, and that schools lacked guidance on their responsibilities for ensuring students with disabilities had access to the proper opportunities (U.S. GAO, 2010).

The Office of Civil Rights makes clear that equal opportunity does not mean every student with a disability is guaranteed a spot on an athletic team for which other students must try out. Schools may require a skill level deemed necessary for participation in a competitive activity or program. Nonetheless, school districts must ensure that a student with a disability is afforded the opportunity to participate with students without disabilities to the maximum extent possible. The guidelines state: "When the interests and abilities of some students with disabilities cannot be fully and effectively met by the school district's existing extracurricular athletic program, the school district should create additional opportunities for those students with disabilities" (U.S. OCR, 2013, p. 11). In these cases, school districts need to offer adapted athletic opportunities for students with disabilities, such as creating a wheelchair basketball or power soccer team (Lakowski, 2013).

A focus on the "interests and abilities" of students with disabilities is strikingly similar to the language the OCR adopted in its interpretation and implementation of Title IX of the Education Amendment of 1972. Title IX reads: "No person in the United States shall, on the basis of sex, be excluded from participation in, be denied the benefits of, or be subjected to discrimination under any education program or activity receiving federal financial assistance" (OCR, 2012, p. 1).

Although Title IX protects against sex discrimination in all educational activities, the bestknown application of this legislation has been its impact in athletics. The OCR interprets Title IX compliance with a three-pronged test. The first prong relates to substantial proportionality, providing athletic participation opportunities for male and female athletes that are proportionate to the percentage of male and female students. The second prong involves demonstrating a continuing history and expansion of athletic opportunities for the underrepresented sex. Finally, and perhaps most appropriate to our discussion, the third prong relates to accommodating the interests and abilities of the underrepresented sex. Thus, an educational institution is in compliance with Title IX when it meets the interests and abilities of its female students, the traditionally underrepresented sex, even when there are disproportionately fewer females than males participating in sports (U.S. Commission on Civil Rights, 2010). 
Similar to the anti-discrimination mandates underlying Title IX of the Education Amendments of 1972, Section 504 of the Rehabilitation Act of 1973 is a Federal law designed to protect the rights of individuals with disabilities in programs and activities (including traditional public schools and charter schools) that receive Federal financial aid. But unlike the positive effects of Title IX on the increased participation rates of girls and young women in college athletics since the 1970's (Coakley, 2009; Van Rheenen, 2012), limited progress has been made in increasing athletic opportunities for youth with disabilities in the United States. Despite efforts to promote exercise and physical activity nationwide, data indicate that there has been little change in the level of physical activity participation among people with a disability in the U.S. over the past decade (National Center on Health, Physical Activity and Disability [NCHPAD], 2012). The President's Council on Physical Fitness and Sports Research Digest reported that physical activity is 4.5 times lower for children and youth with disabilities in the U.S. than their peers without disabilities (NCHPAD, 2016; Rimmer, 2008; U.S. Department of Education Office of Special Education and Rehabilitative Services, 2011).

The traditional foundation of antidiscrimination civil rights legislation in the United States holds that all people must be treated equally, regardless of age, sex, race, religion, or national origin. But, as Miller (1997) argues:

the traditional civil rights model of treating people "exactly the same" does not apply to disability discrimination. For people with disabilities who need reasonable accommodations in order to perform the essential functions of their jobs, "equal" treatment is tantamount to a barrier to employment, not a gateway. (p. 514)

Despite the best intentions of the traditional civil rights model, the adjudication of antidiscrimination legislation seldom, if ever, treats people "exactly the same." As Brake (2004) argues, "equality itself is misguided in law and in theory" (p. 523). Separate but equal statutes and leveling down have both been proposed as remedies to discrimination despite the inherent flaws of such treatments. Brake (2004) calls for "an understanding of equality that transcends a limited right to equal treatment and protects against the expressive and relational injuries of inequality" (p. 618).

As such, Miller (1997) suggests that there needs to be a new paradigm for disability civil rights, one that recasts the notion of a level playing field into one of an accessible playing field. But as this paper explores, the distinction between equality and accessibility in the work place may be more blurred within educational institutions with actual playing fields, particularly when seeking to accommodate the athletic interests and abilities of students with disabilities. The blurring of conceptual lines becomes even less clear when the playing field also serves as a nontraditional classroom.

\section{Framing the Field: Sport and Disability Studies}

Within the context of legal mandates and paradigm shifts, schools at all educational levels must seek ways to increase opportunities and reduce barriers for physical activity and sport among 
students with disabilities. To date, few educational institutions, particularly at the post-secondary level, have met this national need.

It is estimated that 2.3 million, or approximately 11 percent, of college students nationwide have a disability (NCES, 2016). In the California public college and university system alone, there are over 300,000 students with disabilities (GAO, 2009). In 2014, of the estimated 4,140 colleges and universities nationwide, a mere 24 offered an organized sport opportunity of any kind for students with disabilities (American Collegiate Society for Adapted Athletics, 2014). Within the National Collegiate Athletic Association (NCAA), comprised of 1,281 colleges and universities, very few schools have provided even unofficial intercollegiate competition for student athletes with disabilities.

In 2015, however, the Board of Directors of the Eastern Collegiate Athletic Conference (ECAC), the largest NCAA conference comprised of 300 Division I, II and III institutions, voted to add sport opportunities for athletes with disabilities (ESPN, 2015). One year later:

the ECAC introduced Para sport opportunities through its demonstration events at the ECAC Open Swimming \& Diving Championship and ECAC Outdoor Track \& Field Championship. Through a collaborative effort with the NCAA and U.S. Paralympics, the three organizations intend to increase competitive opportunities at the collegiate level for student-athletes with physical and visual impairments. (ECAC, 2016)

Despite these positive developments and the best intentions of the OCR's guidance statement regarding students with disabilities, U.S. educational institutions face a similar challenge when expected to provide opportunities to the underrepresented sex. The challenge of meeting the athletic interests and abilities of a historically excluded group is that the individuals who comprise that group have had limited opportunities to participate in sports activities. Development of a sports-specific interest presumes the opportunity to participate. The corresponding demonstration of athletic abilities related to this interest likewise presumes participation. As such, before realistically conceiving of competitive athletic programs for students with disabilities, schools at all educational levels must provide minimal recreational opportunities for this population of students; otherwise, there will be no chance to become competent, let alone competitive. Because individuals with disabilities are assumed to lack ability as an all-encompassing condition, the development of athletic abilities seems counter-intuitive to such deficit models of disability. First, a model must exist that will foster opportunity.

\section{The Blueprint: Creating Opportunity. Creating a Course}

In the spring of 2013, the authors helped design a course at the intersection of sport and disability studies. The course introduced students to the scholarship on disability studies framed within the cultural studies of sport. In particular, participants engaged with existing literature on disability studies and the sociology of sport while actively participating in a sport designed for those with visual impairments. The corporeal athletic experience sought to help students better understand disability studies. 
Goalball was an activity first designed to facilitate rehabilitation of veterans with visual impairments returning from World War II (Caliskan et al., 2011); it has been a Paralympic sport since 1976. Goalball athletes compete in teams of three on a court the size of a volleyball court. Competitors try to throw a hard, rubber ball with eight holes and sound bells embedded in it into the opponents' goal. The ball weighs 1.25 kilograms $(2.8 \mathrm{lbs}$.) with a diameter of 24 centimeters (9.4 in.) around. A goalball is slightly smaller and lighter than a regulation basketball. At the Paralympic level, the ball has been clocked at a throwing speed in excess of 60 kilometers (37 mph) per hour (International Blind Sports Federation, 2014). Defenders try to block the ball with their bodies as they listen to the ball's approaching trajectory. The court is marked by tape, covering thin rope or twine so that participants can feel the boundaries of the playing field. Whether visually impaired or not, all participants wear blindfolds (known as black out masks) to ensure a level playing field.

The kinesthetic engagement of students in a sport specifically designed for athletes with visual impairments complemented their learning about disability studies from a historical and theoretical perspective. Prior to the goalball course, the university had never offered students cocurricular participation opportunities in sports designed for people with disabilities. When these sports, such as wheelchair basketball, power soccer, or goalball have been played within campus facilities at this university, participants have been primarily non-students. The space has been offered to outside organizations with minimal effort made to integrate the campus and local disability community. When students have been involved in these athletic opportunities, these opportunities have been offered only as extracurricular activities. The pilot course at this large public university was a modest effort to offer an academic course and sports opportunity to one unique group of students with disabilities. The remainder of the paper describes a blueprint of what the class did, how the class did it, and the obstacles faced along the way. The hope is that this blueprint might be replicated elsewhere, offering an integrated and innovative model of sport and disability studies within U.S. higher education.

\section{Course Curriculum: Desired Learning Outcomes}

The course syllabus began as a relatively simple plan with several broad learning outcomes. The desired learning outcomes for the goalball course were to: (a) increase athletic opportunities for students and community members with visual impairments; (b) provide a co-curricular opportunity for participants with and without disabilities; and (c) increase sensitivity to disability issues through an academic and somatic experience.

Several themes were used throughout the course to increase awareness and educate students on the issues pertinent to the disability community and the field of disability studies. Since participants were playing a sport created for those with visual impairments, the curriculum centered on readings and lectures that focused on the intersection of blindness, sports, and disability studies. This proved advantageous as the curriculum allowed students to more fully integrate their goalball experiences into class discussions and assignments.

Inclusion became one of the defining features of the goalball course. The goalball court as a non-traditional classroom promoted the integration of able-bodied participants and those with disabilities uniting toward a common goal. As an engaged scholarship experience, the course also 
facilitated the integration of campus and community collaboration, relying on the expertise of campus partners and the Adaptive Recreation and Athletics Program (ARAP), a local organization that has served the disability community for over twenty-five years. Campus partners included the Disabled Students Program, the Department of Fitness and Recreational Sports, and the School of Education. The underlying premise of engaged scholarship is to create meaningful collaborative research environments with partners outside of the university and thereby promote reflective engagement among students on broad social issues and interests. In addition to strengthening the campus's commitment to equity, social justice, and civic responsibility, engaged scholarship represents another important tool for critical analysis (Cuthill, 2012; Stanton, 2008) of sport and disability.

The course began by having students reflect through group discussion and in narrative writing on their initial experiences of being blindfolded and of playing a sport designed for people who have visual impairments. This process of self-reflection was essential in facilitating the desired learning outcomes for all participants across the ability-disability spectrum. This documentation likewise allowed students to chronicle their progression of beliefs, understandings, and insights over time.

Course readings and guest lectures allowed participants with visual impairments to become facilitators of greater cultural understanding and share their lived experiences of disabilities with sighted students. This process of collaboration helped to deconstruct normative narratives of disability as deficit. The intentional inversion of blindness as privilege within the course helped break down social barriers among participants and increased sensitivity to dominant constructions of disability.

\section{A Non-traditional Classroom}

The two-credit education course met once per week for two hours over a twelve-week term. The course met in the Wildcat Gym of the Recreational Fitness Center (RFC; pseudonym), the university's largest, most complete fitness center with over 100,000 square feet of activity space. The RFC serves the campus community of faculty, staff, and students. While the facility serves the campus community, students with visual impairments have had limited exposure to this community space. For example, when students with visual impairments were given campus tours at this university, they were not taken to the RFC, implying that this would not be a place of interest to them. Since the establishment of this course, however, tours for students with visual impairments now include the recreational fitness center.

The two hours of class were divided into two components. The first part of class was conducted as an academic seminar, engaging participants in group discussions. These discussions were focused primarily on assigned course readings, such as Rod Michalko's "The Birth of Disability," Tanya Titchkosky's “Looking Blind: A Revelation of Culture's Eye,” and H.G. Wells' The Country of the Blind. The academic component also included invited guest speakers who introduced participants to a range of topics pertinent to sport, disability, and visual impairment.

The second half of the class was devoted to learning, practicing, and playing goalball. This sports component was generally divided into technical skills instruction and game competition 
where these newly acquired skills could be applied. Depending on the demonstrated skill level of participants (and corresponding time within the academic term), more or less time was devoted to developing either technical or gameplay skills.

Both the academic and athletic components of the course were held in the Wildcat Gym of the Recreational Fitness Center. Based upon initial experimentation and student feedback, guest lectures and group discussions were deemed more productive when they took place before goalball instruction. Seminar-like discussions took place on the gym floor, where participants sat in a circle. Once discussions or guest lectures were finished, participants moved fluidly onto the goalball court for practice and competitive play. Given the relative difficulty of moving the group between traditional classroom and gym, creating a non-traditional classroom in the gymnasium was the most effective use of time and space for this pilot course. Traditional university classrooms, like most educational spaces, inadvertently privilege sighted students and implicitly enforce corporeal and social norms. As a result, the gym as non-traditional classroom may have helped to level the academic playing field, just as the sport of goalball sought to level the playing field for students with visual impairments.

The faculty member and two Graduate Student Instructors (GSIs) enrolled in the Athletics and Higher Education M.A. program took primary responsibility for facilitating class discussions and inviting guest speakers while the goalball coaches from ARAP taught practice drills and officiated game play. Although course facilitators played different roles and had distinct areas of expertise, instructors were involved in all aspects of the course. GSIs participated fully in sport instruction and training. Conversely, goalball instructors were included in group discussions, often providing critical insights into the connections between course readings and the practice of sport for those with visual impairments. This integrated model allowed the academic and athletic components of the course to complement one other, creating an effective, engaged scholarship opportunity.

\section{If You Build It, Will They Come? Recruitment and Outreach of Participants}

In the American fantasy movie, Field of Dreams (1989), an Iowa corn farmer hears a voice telling him, "If you build it, [they] will come." A preposterous notion, he plows his field and builds a baseball stadium in the middle of nowhere. By the end of the film, they come in droves. Our idea of creating a university goalball course was far less preposterous, but simply offering an athletic opportunity by building a playing field for students with disabilities did not ensure that they would participate.

One of the greatest obstacles in providing extra or co-curricular opportunities for students with disabilities is recruiting and actively engaging these very students. Ironically, the primary target group for the goalball class - students who have visual impairments - turned out to be the hardest group to enroll. This obstacle confirms research demonstrating that students with disabilities engage in sport and physical activity far less than students without disabilities (NCHPAD, 2016; Rimmer, 2008; Rimmer, Riley, Wang, Rauworth \& Jurkowski, 2004). The difficulty in recruiting students who have visual impairments may also reflect the dilemma of developing athletic interests among a population historically excluded from sports participation opportunities. The challenge of recruitment may also reflect a lack of such opportunities at the K- 
12 levels. It is also important to note that exercise participation varies by age and type of physical disability (Cooper, Quatrano, Axelson \& Harlan, 1999; Jaarsma, Dijkstra, Geertzen \& Dekker, 2014; Rimmer, 2006). Risk of injury and the associated fears of athletic participation may impact many individuals with physical disabilities, but this fear may be especially greater among those with visual impairment (Moran \& Block, 2010; Murphy \& Carbone, 2008; Rimmer et al., 2004; Shields, Synnot \& Barr, 2012). Thus, as a beginning goalball course, we advertised that neither experience nor demonstrated ability was a pre-requisite for enrollment.

Outreach efforts were focused specifically on recruiting students who have visual impairments. These efforts included emailing the course description through the campus's Disabled Students Program (DSP) office, making announcements in courses offered within the Disability Studies minor, and posting information on social media outlets such as Facebook. In fall 2014, the goalball course was advertised on the university's student-led course website, a popular portal for students seeking classes on a variety of unorthodox subjects. These courses are often created by students for students. This latter method of recruitment yielded the most interest from students, but these prospective students were almost entirely sighted and non-disabled. Thus, to meet a minimum requirement of students in the class, we recruited students of all abilities, with and without visual impairment, to join the course.

\section{Outreach to the Campus and Local Community with Visual Impairments}

To increase the number of participants with visual impairments, however, outreach efforts also included inviting non-student community participants, all of whom identified as blind or visually impaired. As a result of this effort, community participation likewise increased participation among students with visual impairments, as word spread about the goalball course on campus.

Community participants with visual impairments reported that they benefited from the experience of joining the university's goalball class. Although community members did not earn academic credit and were therefore not required to participate in the academic component of the course, many voluntarily participated in class discussions and attended guest lectures. Exposing community participants with visual impairments to this university course led them to reflect on their own potential educational trajectories. For example, one community participant reported that he planned to apply to a four-year institution the following term, largely because of his involvement in the goalball course at this university. Thus, providing an athletic opportunity to community members with disabilities further enhanced these participants' exposure and confidence in pursuing other educational opportunities.

\section{Logistical Challenges of Community Participation: Liability Waiver and Scholarship Solutions}

Initially, gym compliance policies pertaining to community participants who were not enrolled students created several logistical challenges. Community participants needed to sign a release of liability and purchase a community membership. Unfortunately, consistent with figures that show adults with disabilities have the highest unemployment rate in the United States (U.S. 
Department of Labor, 2014), many in the visually impaired community could not afford the membership fees associated with the goalball course.

To overcome these challenges, the university's Recreational Fitness Center established a membership scholarship program to waive community participant fees. The program stipulated that fees would be waived if applicants with disabilities could verify their income status. Lowincome status could be confirmed through enrollment in the Social Security Income program for the disabled (SSI) or in a documented subsidy plan with the local utility company. If none of this paperwork could be provided, the community member had the option of speaking with a recreational sports facility manager. At the manager's discretion, she could waive membership fees to the community member. No community member who wanted to participate in the goalball course was denied participation, thus reaffirming the course's scholarly theme of inclusion.

While there was significant latitude regarding membership fees, signing a release of liability was required for participation in the goalball course. Though roughly half of the community participants sought membership waivers, all community members signed liability releases. These forms allowed community participants to access the gym and class at no cost, while still protecting the campus and the Department of Fitness and Recreational Sports from liability associated with injury incurred by community members while at the facility.

Having resolved a number of logistical obstacles, students and community members entered the campus fitness center to participate in the university's first goalball course. During the first weeks of the semester, course facilitators had to lead visually impaired participants into an elevator or up a flight of carpeted stairs to the Wildcat Gym of the RFC. Eventually, participants with visual impairments were able to navigate their own paths to the gym without assistance.

The Recreational Fitness Center made significant efforts to create an inclusive space in support of Universal Design. A concept from the field of architecture, Universal Design is "a framework for the design of places, things, information, communication and policy to be usable by the widest range of people operating in the widest range of situations without special or separate design" (IHCD, 2015). Increasingly, Universal Design has been applied as an effective approach and management strategy to enhance educational access to students with disabilities (Burgstahler, 2015; Hums, Schmidt, Novak \& Wolff, 2016; Mcguire, Scott \& Shaw, 2006).

Perhaps as a result of successful facility design, coupled with participant experience in the goalball course, several of the students with visual impairments returned to the RFC to partake in other fitness opportunities, such as using the weight room and cardio equipment. Such results show the importance of providing opportunities to create demand at all educational levels rather than waiting for demand to justify opportunity.

\section{Building the Court. Courting the Building}

Goalball is best played inside an indoor gym or large area with a hardwood floor. The court is the same dimension as a volleyball court $(18 \mathrm{mx} 9 \mathrm{~m})$. It is therefore ideal to use a gym space with volleyball court markings as it expedites practice and game preparation. Because the sport requires blindfolded participants to listen to officials and the sound of an audible ball, it is imperative that 
the gym be as quiet as possible. As such, goalball cannot be played next to noisy spaces, such as other athletic courts or weight rooms. This requirement meant using one of two adjacent courts in the Wildcat Gym on Friday afternoons.

At the start of the semester, facilitators met with some resistance, particularly from pickup basketball players, who had been displaced from this space previously known to them as "open gym." Because the time and space were devoted to an actual course at the university, however, facilitators were able to stress the relative importance of this co-curricular activity. On this campus, like many large universities, the demand for classrooms, gyms, and playing fields far exceeds supply, especially during peak hours. As such, the reservation and use of these spaces is highly prized. Fortunately, the Department of Fitness and Recreational Sports was a founding partner in the development of this course and has always been able to secure the necessary space to create this non-traditional classroom. For institutions wanting to replicate such a course, it is essential for course facilitators to court campus or community partners who control these needed resources to secure gym space, particularly when providing athletic activities for individuals with disabilities (Hums et al., 2016; Spengler, Connaughton \& Carroll, 2011). This process of collaboration should happen before buying the necessary equipment and mapping out a goalball court.

\section{Goalball Equipment}

Disability sports, such as wheelchair basketball, power soccer, and sled hockey are often expensive to sponsor due to specialized equipment needs. For example, just one power soccer wheelchair costs thousands of dollars to purchase (Power Soccer Shop, 2017). Conversely, developing a goalball curriculum is relatively affordable. Almost all of the equipment needed to begin a goalball program can be purchased at a local home improvement or sporting goods store for less than five hundred dollars. The purchase of higher-end products, such as eyeshades, will increase the overall cost of creating and maintaining a goalball program. Only the specialized goalball, which cost between $\$ 60$ - $\$ 80$ per ball, will need to be ordered. Once the basic equipment has been purchased, the recurring equipment needs will cost less than $\$ 100$ per academic term. Thus, for educational institutions seeking to offer extra or co-curricular athletic opportunities for students with disabilities, goalball provides an attractive pilot program.

\section{Recommendations and Future Directions}

Despite its myriad successes, the development and implementation of the goalball course at this large public university consistently prompted philosophical and pedagogical questions. These questions persist even as the course is offered for the sixth consecutive semester. In part because of the initial challenges associated with recruiting students who have visual impairments to participate in the sport of goalball as a co-curricular, co-educational activity, the authors developed an integrated model of engaged scholarship. The model integrated campus and community partners, participants with and without visual impairment, and academic and athletic curriculum. Such a model could be applied to other adaptive sports (e.g., wheelchair basketball, power soccer, sit down volleyball, etc.) in the future. Thus, what emerged at this university could potentially be a blueprint for other colleges and universities. 
While the model has provided an enriching educational experience for participants at this particular institution by integrating communities and increasing sensitivity to diversity issues, future programs and courses might choose to focus solely on providing opportunities for the disability community. Given the historical exclusion of students with disabilities from organized physical education and sports in U.S. schools, separate programs specifically designed for these students may be a necessary first step in developing athletic interests and abilities among this population. These adapted physical education programs, particularly in primary and secondary schools, can help engender greater corporeal confidence, self efficacy, and self-esteem (Brittain, 2004; Scarpa, 2011; Wickman, Nordlund \& Holm, 2016). Such segregated, specialized programs may be less intimidating for students with disabilities who seek educational spaces that normalize disability and offer a safer place to be active in our schools.

Similar programs should be offered in colleges and universities. However, separate but equal efforts seldom make historically disenfranchised groups feel equal (Brake, 2004; Miller, 1997; Olkin, 2002; Tokarz, 1985). Given the observed experiences of this class, the benefits of integration, at least at the post-secondary level, warrant the replication of pilot programs such as the goalball course at this university. Not only did participants with disabilities play with and against able-bodied students, breaking down social barriers within this non-traditional classroom, the integration of male and female participants deconstructed traditional gender divisions commonly reproduced within the U.S. sport culture.

The goalball course was initially designed for beginners. The curriculum allowed students to experience a sport developed for those with visual impairments while introducing them to the basic philosophies of disability studies. Thus, this class provided a unique athletic opportunity for students with disabilities in accordance with the Office of Civil Rights guidelines. With greater opportunity, however, interests and abilities develop, prompting the need for additional opportunities. Instead of a singular course for beginning students offered in subsequent semesters, experienced goalball players and students versed in the basic tenets of disability studies are now on campus. The authors have consequently created additional, advanced-skills sections of the course and a competitive team for those who wish to continue to play.

Better players seek higher levels of competition and the opportunity to compete. Offering an intermediate and/or advanced goalball course could lead to open gym recreational hours for goalball, the creation of a competitive club team, and even an NCAA sponsored sport for students with disabilities.

Such ambitious goals pose ethical questions regarding eligibility and the importance of educational values underlying participation rights. For example, who can and who should represent the educational institution in organized competition of this kind? Should sports such as goalball be restricted to students with disabilities? Should able-bodied students and/or community members be eligible to compete on these rosters? Should these sports be co-ed or gender specific, suggesting ways in which opportunities for students with disabilities could either replicate or challenge the historical implementation of Title IX legislation? If goalball becomes an NCAA sponsored sport, at what division would colleges and universities compete? As the level of competition increases, will a winning-at-all-costs mentality undermine the educational rationale for participation? These 
questions lead one to wonder whether this sport might be better off left alone by the NCAA entirely.

Educational institutions may choose to offer goalball as an extra-curricular athletic opportunity, forgoing the academic component of this pilot course. Such a decision would certainly simplify the implementation of a university goalball program. Creating a co-curricular opportunity produces several advantages, however. The combination of physically experiencing a sport designed for individuals with visual impairments while simultaneously reading and writing about disability studies created a more deliberate cross-disability space for critical inquiry into ableist culture (Titchkosky, 2005). Student self-reflection was enlivened as these participants grappled with concepts and ideas discovered through academic and literary texts.

The goalball course likewise explored a novel area within disability studies, providing an opportunity to apply concepts such as embodiment within a non-traditional classroom. The authors know of no other previous examples where the somatic experience of learning to play a sport designed for athletes with visual impairment has been paired with studying theories of disability in a campus gymnasium rather than classroom. From a curricular perspective, opening the field of play for students with and without disabilities heightened cultural awareness and created alliances among unlikely partners. Beyond the unique university-community partnership forged as a result of this project, students and community members with and without physical disabilities learned from one another and broke down cultural and personal barriers (Van Rheenen, 2016). As a potential blueprint for post-secondary institutions, then, this article seeks to contribute to the literature on sport and disability. Physical education courses such as these may become required or elective curriculum for college majors and minors in the growing field of disability studies.

When colleges and universities sponsor these type of extra or co-curricular activities, in support of the OCR's recommendations for providing athletic opportunities for students with disabilities, it is important that educational institutions prioritize and invest in finding the time and space for these activities. While the authors were able to secure gym space temporarily during this pilot course, the next goal is to permanently build these recreational and competitive athletic spaces for the disability community such as the construction of multi-use facilities for adapted athletics at institutions like the University of Alabama, the University of Illinois and the University of Wisconsin-Whitewater, among others (Bynum, 2007; Hardin, 2017; Reid, 2017). This is a goal best achieved as part of an integrated institutional model based on the inclusive tenets of Universal Design.

Like several sister institutions, students at this university recently passed a campus wellness referendum sponsored by several student groups represented in the university's student government. In addition to improving access to healthcare and enhancing mental health services, the referendum proposes to build a wellness center. The wellness center would offer larger gym facilities, nutritional classes, and universal changing areas, creating spaces for alternative and innovative forms of fitness and therapies available to a larger and more diverse campus community.

\section{Conclusion}


Providing access and opportunity for students with disabilities remains a pressing civil rights issue at all educational levels within U.S. schools. While these efforts must begin at the K12 level, colleges and universities must likewise seek novel ways to address this legislative and ethical mandate. The development and sponsorship of extra and co-curricular athletic activities for this historically marginalized student population does more than simply accommodate individuals with disabilities. These opportunities have the potential to reframe envisioning athletic interests, abilities, and potential. As such, we are hopeful that the design of this novel curriculum contributes to existing literature while simultaneously meeting the legal and ethical mandates of the OCR. The goalball course at this one institution of higher education was a modest and practical effort to level the playing field and envision an innovative future at the intersection of sport and disability.

\section{References}

Allport, G. W. (1954). The nature of prejudice. Cambridge, MA: Perseus Books.

American Collegiate Society for Adapted Athletics. (2014). Resource Center. Retrieved from http://www.acsaaorg.org/resources.php

Asimov, N. (2014, May 4). Cal's disabled students program unites through sports. SF Gate. Retrieved from http://www.sfgate.com/default/article/Cal-s-disabled-studentsprogram-unites-through-5452710.php\#item-29311

Blackstone, J. (Producer). (2013, June 2). Goalball: A game created for the blind [Television broadcast]. New York City, NY: CBS Evening News.

Brake, D.L. (2004). "When equality leaves everyone worse off: The problem of leveling down in equality law." William and Mary Law Review, 46(2), 513-618.

Brittain, I. (2004). Perceptions of disability and their impact upon involvement in sport for people with disabilities at all levels. Journal of Sport and Social Issues, 28(4), 429-452.

Burgstahler, S. E. (2015). Universal design in higher education: From principles to practice. Cambridge, MA: Harvard Education Press.

Bynum, M. (2007, April). Outfitting fitness areas to serve disabled populations. Athletic Business. Retrieved from http://www.athleticbusiness.com/fitnesstraining/outfitting-fitness-areas-to-serve-disabled-populations.html

Caliskan, E., Pehlivanb, A., Erzeybekb, M.S., Kayapinarc, F.C., Agopyanb, A., Yukseld, S., \& Dane, S. (2011). Body mass index and percent body fat in goalball and movement education in male and female children with severe visual impairment. Journal of Neurology, Psychiatry, and Brain Research, 17, 39-41. 
Cerles, P. (2014, September 21). Visually impaired students score in campus goalball team. Daily Californian. Retrieved from http://www.dailycal.org/2014/09/21/visuallyimpaired-students-score-campus-goalball-team/

Chamalian, D. (2000). Gooaaaaal! ball. Questia, 30(8), 32-33.

Coakley, J. (2009). Sports in society: Issues and controversies (10 ${ }^{\text {th }}$ ed.). New York, NY: McGraw-Hill Companies.

Cockrell, C. (2013, April 24). 'Fitness for All' is an exercise in inclusion. UC Berkeley News Center. Retrieved from http://newscenter.berkeley.edu/2013/04/24/fitness-for-allis-an-exercise-in-inclusion/

Cooper, R. A., Quatrano, L. A., Axelson, P. W., \& Harlan, W. (1999). Research on physical activity and health among people with disabilities: A consensus statement. Journal of Rehabilitation Research and Development, 36(2), 142.

Cuthill, M. (2012). A "civic mission" for the university: Engaged scholarship and communitybased participatory research. In L. Mcllrah, A. Lyons, \& R. Munck (Eds.). Higher education and civic engagement: Comparative perspectives (pp.81-99). New York, NY: Palgrave Macmillan U.S.

Ding, T. (2014, March 7). Disability health maintenance program for equal access to health and fitness. The Berkeley Graduate. Retrieved from http://www.theberkeleygraduate.com/2014/03/disability-health-maintenance-program-for-equal-access-tohealth-and-fitness/

Eastern College Athletic Conference. (2016). ECAC announces forward movement for inclusive sport initiative. Retrieved from http://www.ecacsports.com/news/2016/2/23/2_23_2016_36.aspx?path=gen

ESPN (2015). ECAC to add events for disabled. Retrieved from http://www.espn.com/collegesports/story/_id/12231832/ecac-votes-add-opportunities-disabled-athletes

Frankish, B.E., Gordon, C., Gordon, L., \& Levin, L. (Producers), \& Robinson, P. A. (Director). (1989). Field of Dreams [Motion picture]. United States: Universal Pictures.

Hardin, B. (2017). Groundbreaking ceremony February 23. University of Alabama. Retrieved from http://alabamaadapted.com/groundbreaking-ceremony-february-23/

Hums, M. A., Schmidt, S. H., Novak, A., \& Wolff, E. A. (2016). Universal design: Moving the Americans with disabilities act from access to inclusion. Journal of Legal Aspects of Sport, 26(1), 36-51.

Institute for Human Centered Design. (2015). What is Universal Design? Retrieved from http://www.humancentereddesign.org/universal-design 
International Blind Sports Federation. (2014). Goalball Rules and Regulations. Retrieved from http://www.ibsasport.org/sports/goalball/rules/

Jaarsma, E. A., Dijkstra, P. U., Geertzen, J. H. B., \& Dekker, R. (2014). Barriers to and facilitators of sports participation for people with physical disabilities: A systematic review. Scandinavian Journal of Medicine \& Science in Sports, 24(6), 871-881.

Kell, G. (2014, September 22). New athletic team breaks barriers for the disabled. U.C. Berkeley News Center. Retrieved from http://newscenter.berkeley.edu/2014/09/22/newathletic-team-breaks-barriers-for-the-disabled/

Lakowski, T. (2013). U.S. Department of Education orders sports access for students with disabilities: A watershed moment for students with disabilities. Palaestra, 27(2), 8-11.

Mabanta, A. (2013, May 13). Introducing goalball, Cal's most inclusive sport. The Daily Clog. Retrieved from http://www.dailycal.org/2013/05/13/introducing-goalball-cals-most-inclusive-sport/

Mcguire, J. M., Scott, S. S., \& Shaw, S. F. (2006). Universal design and its applications in educational environments. Remedial and special education, 27(3), 166-175.

Melendez, L. (2013, April 29). UC Berkeley students test sport designed for visually impaired. ABC 7 News. Retrieved from http://abc7news.com/archive/9081587/

Michalko, R. (2002). The difference that disability makes. Philadelphia: Temple University Press.

Miller, P.S. (1997). Disability civil rights and a new paradigm for the twenty-first century: The expansion of civil rights beyond race, gender, and age. University of Pennsylvania Journal of Labor and Employment Law, 1(2), 511-526.

Moran, T. E., \& Block, M. E. (2010). Barriers to participation of children with disabilities in youth sports. TEACHING Exceptional Children Plus, 6(3), n3.

Murphy, N. A., \& Carbone, P. S. (2008). Promoting the participation of children with disabilities in sports, recreation, and physical activities. Pediatrics, 121(5), 1057-1061.

National Center on Health, Physical Activity and Disability (2012). Trends in physical activity: Are we moving fast enough? Retrieved from http://www.nchpad.org/231/1528/Trends in Physical Activity Are We Moving Fast $\sim$ Enough \#sthash.7QTaUpQt.dpuf

National Center on Health, Physical Activity and Disability (2016). Let's move towards active inclusive schools. Retrieved from https://health.gov/news/blog-bayw/2016/04/letsmove-towards-active-inclusive-schools/ 
Olkin, R. (2002). Could you hold the door for me? Including disability in diversity. Cultural Diversity and Ethnic Minority Psychology, 8(2), 130.

Power Soccer Shop (2017). Retrieved from http://powersoccershop.com/strikeforcepowerwheelchairandsoccerguard.aspx)

Reid, T. (2017). University of Alabama breaks ground on one-of-a-kind adapted athletics facility. WIAT News. Retrieved from http://wiat.com/2017/02/23/university-ofalabama-breaks-ground-with-one-of-a-kind-adapted-athletics-facility/

Rimmer, J. H. (2006). Use of the ICF in identifying factors that impact participation in physical activity/rehabilitation among people with disabilities. Disability and Rehabilitation, 28(17), 1087-1095.

Rimmer, J. H. (2008). Promoting inclusive physical activity communities for people with disabilities. President's Council on Physical Fitness and Sports Research Digest, 9(2), 18.

Rimmer, J. H., Riley, B., Wang, E., Rauworth, A., \& Jurkowski, J. (2004). Physical activity participation among persons with disabilities: Barriers and facilitators. American Journal of Preventive Medicine, 26(5), 419-425.

Scarpa, S. (2011). Physical self-concept and self-esteem in adolescents and young adults with and without physical disability: The role of sports participation. European Journal of Adapted Physical Activity, 4(1).

Seligman, K. (2014). Goalball in blindfolds, soccer in wheelchairs: Cal busts barriers to competitive sports. Cal Alumni Association. Retrieved from http://alumni.berkeley.edu/california-magazine/just-in/2014-02-12/goalball-blindfolds-soccer-wheelchairscal-busts-barriers

Shields, N., Synnot, A. J., \& Barr, M. (2012). Perceived barriers and facilitators to physical activity for children with disability: A systematic review. British Journal of Sports Medicine, 46(14), 989-997.

Slininger, D., Sherrill, C., \& Jankowski, C. M. (2000). Children's attitudes toward peers with severe disabilities: Revisiting contact theory. Adapted Physical Activity Quarterly, 17(2), 176-196.

Spengler, J. O., Connaughton, D. P., \& Carroll, M. S. (2011). Addressing challenges to the shared use of school recreational facilities. Journal of Physical Education, Recreation \& Dance, 82(9), 28-33.

Stanton, T. K. (2008). New times demand new scholarship: Opportunities and challenges for civic engagement at research universities. Education, Citizenship and Social Justice, 3(1), $19-42$. 
Titchkosky, T. (2005). Looking blind: A revelation of culture's eye. In C. Sandahl \& P. Auslander (Eds.), Bodies in commotion: Disability and performance (pp. 219-230). Ann Arbor, MI: University of Michigan Press.

Tokarz, K. L. (1985). Separate but unequal educational sports programs: The need for a new theory of equality. Berkeley Women's Law Journal, 1, 201.

Tripp, A., French, R., \& Sherrill, C. (1995). Contact theory and attitudes of children in physical education programs toward peers with disabilities. Adapted Physical Activity Quarterly, 12, 323-323.

University of California Television (2013). Goalball Course at UC Berkeley. Retrieved from https://www.youtube.com/watch?v=h3fjof_B-Is

U.S. Commission on Civil Rights (2010). Title IX athletics: Accommodating interests and abilities. Retrieved from http://www.usccr.gov/pubs/TitleIX-2010-rev100610.pdf

U.S. Department of Education, National Center for Education Statistics. (2016). Digest of education statistics. Retrieved from https://nces.ed.gov/fastfacts/display.asp?id=60

U.S. Department of Education, Office for Civil Rights. (2012). Title IX enforcement highlights. Washington, D.C. Retrieved from https://www2.ed.gov/documents/pressreleases/title-ix-enforcement.pdf

U.S. Department of Education, Office for Civil Rights. (2013). Students with disabilities in extracurricular athletics. Retrieved from http://www2.ed.gov/about/offices/list/ocr/letters/colleague-201301-504.pdf

U.S. Department of Education Office of Special Education and Rehabilitative Services, Office of Special Education Programs. (2011). Creating equal opportunities for children and youth with disabilities to participate in physical education and extracurricular athletics. Retrieved from http://www2.ed.gov/policy/speced/guid/idea/equal-pe.pdf

U.S. Department of Labor, Office of Disability Employment Policy (2014). Disability employment statistics. Retrieved from http://www.dol.gov/odep/

U.S. Government Accountability Office. (2009). Higher education and disability: Education needs a coordinated approach to improve its assistance to schools in supporting students. Retrieved from http://www.gao.gov/new.items/d1033.pdf

U.S. Government Accountability Office. (2010). Students with disabilities: More information and guidance could improve opportunities in physical education and athletics. Retrieved from: http://www.gao.gov/assets/310/305770.pdf

Van Rheenen, D. (2012). A century of historical change in the game preferences of American children. Journal of American Folklore, 125(3), 411-443. 
Van Rheenen, D. (2016). The blind leading the blind: Goalball as engaged scholarship. Journal of Postsecondary Education and Disability, 29(1), 25-34.

Wells, H.G. (2007). The country of the blind and other selected stories. London: Penguin Books.

Wickman, K., Nordlund, M., \& Holm, C. (2016). The relationship between physical activity and self-efficacy in children with disabilities. Sport in Society, 1-14. 